\title{
Receptors of the enteric nervous system: potential targets for drug therapy
}

J Tack

It is recognised that the enteric nervous system (ENS) has a unique ability to mediate reflex activity independently of input from the brain or spinal cord..$^{1-4}$ This ability implies that the ENS contains sensory receptors, primary afferent neurones, interneurones, and motor neurones. The events that are controlled, at least in part, by the ENS are multiple and include motor activity, secretion, absorption, blood flow, and interaction with other organs such as the gall bladder or pancreas. ${ }^{1-4}$

The extensive regulatory activities of the ENS are made possible by the presence and abundance of different types of neurones within the wall of the gastrointestinal tract. The ENS contains about $10^{8}$ neurones, approximately the number of neurones found in the spinal cord. Morphological, electrophysiological, and pharmacological studies have revealed a substantial diversity of neurones within the ENS. Moreover, a surprisingly large number of established or candidate neurotransmitters can be found in enteric neurones. Most neurones contain several of these substances, and distinctive patterns of colocalisation of mediators allow identification of different functional classes of neurones. ${ }^{2}{ }^{3}$ The presence of receptors on enteric neurones is another expression of their heterogeneity. Myenteric neurones can express receptors for both peptide and nonpeptide (amines, amino acids, purines) neurotransmitters. ${ }^{1-5}$ Generally, expression of a receptor is limited to a subset of myenteric neurones, with probably the only exception being expression of nicotinic cholinergic receptors on all myenteric neurones in the guinea pig stomach. ${ }^{6}$ Unfortunately, we know very little about the relationship between the functional role of enteric neurones and their expression of receptors.

The ENS is a target for pharmacotherapy of gastrointestinal disorders

A number of drugs, which are used clinically to alter gastrointestinal motility, act via the ENS. Prokinetic drugs, such as cisapride, motilin and erythromycin, stimulate gastrointestinal motility at least in part through release of acetylcholine from intrinsic cholinergic neurones. ${ }^{89} \mathrm{Cis}-$ apride enhances cholinergic neurotransmission via activation of a presynaptic 5-hydroxytryptamine $(5-\mathrm{HT})_{4}$ receptor. $^{8}{ }^{10}$ In addition, cisapride has a direct postsynaptic excitatory effect on a subpopulation of antral neurones, which is not mediated by a $5-\mathrm{HT}_{4}$ receptor. ${ }^{11}$ Indeed, non-serotonergic effects have also been implicated in the prokinetic actions of cisapride. ${ }^{12}$ Motilin and erythromycin can induce prolonged depolarisation in a subset of neurones in the guinea pig stomach, possibly by activation of a motilin receptor. ${ }^{9}$ However, direct muscular effects are also involved in some of the effects of motilides. ${ }^{13}$ Inhibitors of gastrointestinal motility, such as clonidine, botulinum toxin, or sumatriptan, may inhibit release of acetylcholine or stimulate the release of nitric oxide from intrinsic neurones. ${ }^{14-17}$

The observation that drugs which are used clinically to alter gastrointestinal motility act via the ENS confirms the view that the ENS is a valid target for the pharmacotherapy of gastrointestinal motor disorders.

\section{The ENS as a target for achieving} improved specificity of pharmacological actions

Pharmacological treatment of gastrointestinal motility disorders is intended to stimulate or inhibit motility. Established sites of action of motility drugs are gastrointestinal smooth muscle, the ENS, autonomic ganglia, and the central nervous system. Drugs acting at different sites may cause a similar net effect on gastrointestinal motility. Enhancement of gastrointestinal motility can be achieved by direct stimulation of gastrointestinal smooth muscle, by activation of excitatory neural pathways, or by inhibition of inhibitory pathways. Similarly, inhibition of gastrointestinal motility can be achieved by a direct relaxant effect on gastrointestinal smooth muscle, by inhibition of excitatory neural pathways, or by activation of inhibitory pathways.

When stimulation or inhibition of contractile activity is achieved through agents that act directly on gastrointestinal smooth muscle (for example, cholinergics, cholinesterase inhibitors, nitrates, L-type calcium channel blockers), the effect is often non-specifically present throughout the gastrointestinal tract. Motilides may be an exception to this, as smooth muscular motilin receptors are mainly expressed in the stomach and proximal small intestine in humans. ${ }^{18}$

Most drugs affecting gastrointestinal motility do so by acting as an agonist or antagonist at specific cellular receptors. Stimulation or inhibition of contractile activity through receptors on enteric neuronal circuitry offers the potential of achieving higher specificity. Serotonin 3 $\left(5-\mathrm{HT}_{3}\right)$ receptor antagonists, for example, inhibit colonic motor activity in humans via a neural pathway but they have no clearly demonstrable effect on gastric emptying rate. ${ }^{19} 20$

The selection of a drug therapy with optimal specificity requires both a precise knowledge of

Abbreviations used in this paper: ENS, enteric nervous system; 5-HT, 5-hydroxytryptamine.
Correspondence to: Professor J Tack.

jan.tack@med.kuleuven.ac.be 




Figure 1 Neural pathways mediating gastric accommodation (animal studies). 5-HT, 5-hydroxytryptamine; ACh, acetylcholine; $N O$, nitric oxide.

the type of change in motor behaviour that is required, as well as of the circuitry and the receptors that are involved in its control. This statement is best illustrated by an example. A subgroup of patients with functional dyspepsia has impaired accommodation of the proximal stomach to ingestion of a meal, and this is associated with symptoms of early satiety and weight loss. ${ }^{21}$ Several attempts have been made to improve defective gastric accommodation in these patients. Nitrates can enhance relaxation of the stomach after ingestion of a meal but produce several side effects related to their action on extraintestinal smooth muscle. ${ }^{22}$ In the mouse and guinea pig, involvement of 5-HT receptors on intrinsic neurones in the vagally mediated gastric relaxation has been demonstrated (fig 1). ${ }^{23}$ Selective 5-HT re-uptake inhibitors act both centrally and peripherally to enhance the availability of physiologically released $5-\mathrm{HT}^{24}{ }^{24}$ We demonstrated that a selective 5-HT reuptake inhibitor can enhance gastric accommodation to a meal in humans. ${ }^{25}$ However, probably because such drugs enhance the availability of 5-HT at vagal afferents that are activated by $5-\mathrm{HT}_{3}$ receptors, they are associated with nausea. Hence they are less well suited for therapeutic use in dyspeptic patients. More recently, it was demonstrated that 5-HT induced relaxations of the guinea pig stomach are mediated via release of nitric oxide through activation of a $5-\mathrm{HT}_{1}$-like receptor. ${ }^{26}$ Combining 5-HT responsiveness with immunohistochemical studies in myenteric neurones of the guinea pig stomach revealed that a $5-\mathrm{HT}_{1 \mathrm{P}}$ receptor is present on intrinsic nitrergic neurones (fig 2) ${ }^{27}$ We recently demonstrated that sumatriptan is an agonist at the $5-\mathrm{HT}_{1 \mathrm{P}}$ receptor on gastric antral myenteric neurones. ${ }^{28}$ We confirmed that administration of sumatriptan can improve impaired gastric accommodation in dyspeptic patients with early satiety, with a resultant improvement in early satiety. ${ }^{21}$

The ENS in humans as a target for pharmacotherapy

Selection of a drug therapy with optimal specificity requires a precise knowledge of the



Figure 2 5-Hydroxytryptamine (5-HT) receptors on gastric myenteric neurones. ACh, acetylcholine; $N O$, nitric oxide; Sub P, substance P; VIP, vasoactive intestinal peptide.

circuitry and receptors that are involved in any given motor phenomenon in humans. Unfortunately, our knowledge of the ENS in humans is extremely limited, and most of the information available is extrapolated from animal studies, as has been illustrated above. The availability of human tissue for physiological and pharmacological studies is extremely limited. Hence labourious and slow techniques, such as intracellular electrophysiological studies of receptor responses, are not suitable for studying the human ENS. Immunohistochemical demonstration of receptor expression on human myenteric neurones may be one more fruitful approach. Recently, we investigated the use of optical imaging of neuronal calcium concentration as a technique to study the responsiveness of enteric neurones to neuroligands. This technique, which was validated on cultured myenteric neurones, is also applicable to ex vivo preparations and on neurones that are retrogradely labelled with DiI. ${ }^{29-31}$ In preliminary studies, we demonstrated that circular muscle motor neurones of the guinea pig small intestine showed characteristic responsiveness to groups of neuroligands. We are currently adapting this technique for use on human specimens. 
1 Wood JD. Physiology of the enteric nervous system. In: Johnson LR, ed. Physiology of the gastrointestinal tract, 3rd Johnson LR, ed. Physiology of the gastrointest
edn. New York: Raven Press, 1994:423-82.

2 Furness JB, Costa M. The enteric nervous system. New York: Churchill Livingstone, 1987.

3 Costa M, Brookes SJ. The enteric nervous system. Am $\mathscr{f}$ Gastroenterol 1994;89:S129-37.

4 Goyal RK, Hirano I. The enteric nervous system. $N$ Engl f Med 1996;334:1107-15.

5 Tack JF, Janssens J, Vantrappen O. Characteristics of myenteric neurons in the gastric antrum and their receptor properties. In: Holle GE, Wood JD, ed. Advances in the innervation of the gastrointestinal tract. Amsterdam: Elsevier, 1992:169-79.

6 Schemann M, Wood JD. Synaptic behavior of myenteric neurones in the gastric corpus of the guinea-pig. $\mathcal{F}$ Physiol 1989;417:519-35.

7 Tack JF, Wood JD. Synaptic behaviour in the myenteric plexus of the guinea-pig gastric antrum. I Physiol plexus of the guin.

8 Tonini M, Galligan JJ, North RA. Effects of cisapride on cholinergic neurotransmission and propulsive motility in the guinea-pig ileum. Gastroenterology 1989;96:1257-64.

9 Tack J. Motilin and the enteric nervous system in the contro of interdigestive and postprandial gastric motility. Acta Gastroenterol Belg 1995;1:21-30.

10 Pan H, Galligan JJ. 5-HT1A and 5-HT4 receptors mediate inhibition and facilitation of fast synaptic transmission in enteric neurons. Am F Physiol 1994;266:G230-8.

11 Tack J, Vanden Berghe P, Janssens J. Actions of cisapride on myenteric neurons in the guinea-pig gastric antrum. Submitted for publication, 1999.

12 De Ridder WJ, Schuurkes JA. Cisapride and 5-hydroxytryptamine enhance motility in the canine antrum via separate pathways, not involving 5-hydroxytryptaminel,2,3,4 receptors. I Pharmacol Exp Ther 1993;264:79-88.

13 Coulie B, Tack J, Peeters T, et al. Involvement of two different pathways in the motor effects of erythromycin on the ent pathways in the motor effects of erythromyci

14 Pasricha PJ, Ravich WJ, Hendrix TR, et al. Intrasphincteric botulinum toxin for the treatment of achalasia. $N$ Engl f Med 1995;332:774-78.

15 Pasricha PJ, Ravich WJ, Kalloo AN. Effects of intrasphincteric botulinum toxin on the lower esophageal sphinter in piglets. Gastroenterology 1993;105:1045-9.

16 Tack JF, Wood JD. Actions of norepinephrine on myenteric neurones in the gastric antrum of the guinea-pig. F Auton Nerv Syst 1992;41:67-78.

17 Coulie B, Tack J, Sifrim D, et al. Role of nitric oxide in fasting gastric fundus tone and in 5-hydroxytryptamine-1 receptor-mediated relaxation of the gastric fundus. $A m \mathcal{F}$ Physiol 1999;276:G373-7.
18 Peeters TL, Matthijs G, Depoortere I, et al. Erythromycin is a motilin receptor agonist. Am f Physiol 1989;237:G470-4.

19 Nielsen OH, Hvid-Jacobsen K, Lund P, et al. Gastric emptying and subjective symptoms of nausea: lack of effects of 5-hydroxytryptamine-3 antagonist ondansetron on gastric emptying in patients with gastric stasis syndrome. Digestion 1990;46:89-96.

20 Talley NJ, Phillips SF, Haddad A, et al. GR 38032F (ondansetron), a selective 5-HT3 receptor antagonist, slows colonic transit in healthy man. Dig Dis Sci 1990;35:477-80.

21 Tack J, Piessevaux H, Coulie B, et al. Role of impaired gastric accommodation to a meal in functional dyspepsia. Gastroenterology 1999;115:1346-52.

22 Hausken T, Gilja OH, Odegaard S, et al. Effects of glyceryl trinitrate on transpyloric flow of a soup meal. Scand f Gastroenterol 1998;33:484-90.

23 Bülbring E, Gershon MD. 5-Hydroxytryptamine participation in the vagal inhibitory innervation of the stomach. $\mathcal{F}$ Physiol 1967;192:823-46.

24 Gershon MD, Jonakait GM. Uptake and release of 5-hydroxytryptamine by enteric 5-hydroxytryptaminergic neurons: effects of fluoxetine (Lilley 110140) and chlorimipramine. Br f Pharmacol 1979;66:7-9.

25 Tack J, Broekaert D, Coulie B, et al. Involvement of 5-hydroxytryptamine in the control of the accommodation reflex in man. Submitted for publication.

26 Meulemans AL, Helsen LF, Schuurkes JAJ. The role of nitric oxide (NO) in 5-HT induced relaxations of the guinea-pig stomach. Naunyn Schmiedebergs Arch Pharmacol 1993;384:424-30.

27 Michel K, Sann H, Schaaf C, et al. Subpopulations of gastric myenteric neurons are differentially activated via distinct serotonin receptors: projection, neurochemical coding, and functional implications. F Neurosci 1997;17:8009-17.

28 Tack J, Vanden Berghe P, Coulie B, et al. Sumatriptan is an agonist at $5-\mathrm{HT}_{1 \mathrm{P}}$ receptors on myenteric neurons in the guinea-pig gastric antrum. Submitted for publication.

29 Vanden Berghe P, Tack J, Coulie B, et al. Synaptic transmission induces transient calcium concentration changes in cultured myen Vanden Berghe P, Tack J, Andrioli A, et al. Effect of excita-
tory neurotransmitters on intracellular $\mathrm{Ca}^{2+}$ signaling in tory neurotransmitters on intracellular $\mathrm{Ca}^{2+}$ signaling in
cultured myenteric neurons. Am f Physiol 2000;278:G90514 .

31 Vanden Berghe P, Molhoek S, Missiaen L, et al. Differential $\mathrm{Ca}^{2+}$ signaling characteristics of inhibitory and excitatory myenteric motor neurons in culture. Am f Physiol 2000 (in press). 